\title{
Tumour necrosis factor $\alpha$ stimulated rheumatoid synovial microvascular endothelial cells exhibit increased shear rate dependent leucocyte adhesion in vitro
}

\author{
S E Abbot, W J D Whish, C Jennison, D R Blake, C R Stevens
}

\begin{abstract}
Objective-To investigate endothelial cell adhesion molecule expression and leucocyte adhesion to endothelial cells isolated from the microvasculature of rheumatoid arthritic synovial tissue (SMEC) in comparison with similar cells isolated from healthy subcutaneous adipose tissue (ADMEC) or from umbilical veins (HUVEC).

Methods-Cultured endothelial cells were treated with tumour necrosis factor $\alpha$ (TNF $\alpha$ ) for 2-24 hours before the assessment of cell surface E-selectin, vascular (VCAM-1) or intercellular cell adhesion molecule-I (ICAM-1) expression. Neutrophil and $T$ lymphocyte adhesion to TNF $\alpha$ treated endothelial cells was assessed using static and shear dependent assay systems.

Results-VCAM-1 expression by SMEC was significantly less sensitive to TNFo stimulation than HUVEC or ADMEC. E-selectin expression by SMEC appeared to be more sensitive to $\mathrm{TNF} \alpha$ stimulation and maximal expression was about $30 \%$ greater in comparison with HUVEC or ADMEC. Sensitivity to TNF $\alpha$ induction and maximal ICAM-1 expression was similar in all three endothelial cell types. Static neutrophil adhesion to TNFo stimulated SMEC was significantly increased in comparison with HUVEC, however this phenomenon was dependent on the presence of neutralising antibodies to ICAM-1. At shear rates in excess of 2.4 dynes $/ \mathrm{cm}^{2}$ significantly more neutrophils and, predominantly CD45RO+, T lymphocytes adhered to TNF $\alpha$ stimulated SMEC than HUVEC.

Conclusion-Rheumatoid synovial endothelial cells differentially regulate E-selectin and VCAM-1. The increased ability of TNFa stimulated synovial endothelial cells to support leucocyte adhesion may help to explain the leucocyte, in particular CD45RO+ T-lymphocyte, recruitment observed in the rheumatoid synovium.
\end{abstract}

(Ann Rheum Dis 1999;58:573-581)

Dr S E Abbot, Department of Pharmacy and

Pharmacology, University of Bath, Claverton Down, Bath, BA2 7AY.

Accepted for publication 4 May 1999 large extravascular accumulation of leucocytes, primarily neutrophils and lymphocytes. ${ }^{1}$ It is now well established that $\mathrm{T}$ lymphocytes are the predominant perivascular lymphocytes in the rheumatoid synovium. ${ }^{2}$ Although normal numbers of peripheral blood CD4+/CD29+ or CD4+/CD45RO+ "memory" and CD4+/ CD45RA+ "naive" $T$ cells are usually found in rheumatoid patients, in the synovial membrane nearly all of the $\mathrm{T}$ cells display a $\mathrm{CD} 4+$ / CD45RO+ "memory" phenotype with very few cells displaying a "naive" phenotype. ${ }^{3}$ The mechanisms governing leucocyte, specifically CD4+/CD45RO+ cell, accumulation in inflamed synovial tissue remain to be elucidated.

A critical early event governing leucocyte extravasation is the local expression of cellular adhesion molecules (CAMs) promoting the attachment of circulating leucocytes to small vessel endothelium. Current dogma suggest a sequential cascade of adhesion events in which transient, selectin mediated, cell interactions promote more permanent immunoglobulinintegrin mediated cell-cell adhesion and leucocyte diapedesis. Many hypotheses have been suggested to explain the selective recruitment of leucocyte sub-classes into inflamed tissues, however the prospect of different cellular adhesion molecules specifically mediating interactions between different leucocyte subpopulations has been enduringly attractive. Traditionally, interactions between E-selectin (ELAM-1, CD62E) and its ligands were thought to mediate neutrophil diapedesis specifically. ${ }^{4-6}$ However, E-selectin is highly expressed at inflammatory sites where the cellular infiltrate is predominantly mononuclear ${ }^{78}$ and more recently E-selectin has been implicated as a vascular addressin in the control of CD45RO+ memory $\mathrm{T}$ lymphocyte diapedesis. ${ }^{9-12}$ Likewise, interactions between vascular cell adhesion molecule-1 (VCAM-1, CD106) and the $\beta_{1}$ integrin, very late activation antigen-4 (VLA-4) were initially thought to control monocyte diapedesis, ${ }^{13}$ however, VCAM-1 / VLA-4 mediated cell interactions are now known to be common among leucocyte classes and may even perform a similar function to that of selectins in mediating dynamic cell interactions. ${ }^{14}$

Increased E-selectin expression in rheumatoid synovial tissue has been demonstrated by immunohistochemical analysis. ${ }^{15} \mathrm{~T}$ lymphocytes isolated from rheumatoid synovial tissue display increased binding to plastics coated with human recombinant E-selectin or VCAM-1 and analysis of the bound population revealed a predominance of memory $T$ lymphocytes. ${ }^{12}$ This study suggested that 
interaction of CD45RO+ T lymphocytes with endapproximately $3 \mathrm{~mm}^{3}$ tissue pieces. With the thelial E-selectin may upregulate VCAM-1/ VLA-4 mediated interactions in a similar manner to neutrophil interaction with endothelial cell E-selectin upregulating ICAM-1/MAC-1 (CD18/CD11b) mediated interactions. ${ }^{16}$ Other studies have shown that while ICAM-1/LFA-1 interactions were important in the binding of $\mathrm{T}$ cells to unstimulated endothelium, VCAM-1/ VLA-4 interactions act as the main mediators of $\mathrm{T}$ cell adhesion to interleukin 1 (IL1) stimulated endothelial cells. ${ }^{17}$

We have shown previously that isolated synovial microvascular endothelial cells (SMEC) express significantly higher levels of E-selectin on their cell surface than human umbilical vein endothelial cells (HUVEC) in response to stimulation with IL1. ${ }^{18}$ The aims of this study were to investigate the effects of tumour necrosis factor $\alpha(\mathrm{TNF} \alpha)$, stimulation on E-selectin, VCAM-1 and ICAM-1 expression by isolated SMEC in comparison to HUVEC and adipose derived microvascular endothelial cells (ADMEC) and to examine the relative importance of adhesion molecule expression in neutrophil and $\mathrm{T}$ lymphocyte adhesion to these cell types. Leucocyte adhesion was measured using standard static binding assays in conjunction with antibody adhesion blockade and also a physiologically relevant dynamic binding assay. Adherent $\mathrm{T}$ lymphocyte sub-populations were assessed for expression of the memory cell marker CD45RO by indirect immunofluorescence.

\section{Methods}

Unless otherwise stated reagents were purchased from Sigma Chemical Co Ltd, Poole, UK.

ENDOTHELIAL CELL CULTURE

HUVEC were isolated and cultured using methods modified from those described by Jaffé. ${ }^{19}$ Briefly, endothelial cells were isolated by collagenase perfusion of umbilical cord veins obtained from normal full term deliveries. Isolated cells were grown in Medium 199 (Gibco BRL, Paisley) containing $30 \mu \mathrm{g} / \mathrm{ml}$ endothelial cell growth supplement (ECGS), $20 \% \mathrm{v} / \mathrm{v}$ heat inactivated fetal calf serum (FCS) (Biological Industries, Glasgow), $17 \mathrm{U} / \mathrm{ml}$ heparin (CP Pharmaceuticals, Wrexham), 50 $\mathrm{U} / \mathrm{ml}$ penicillin, $50 \mu \mathrm{g} / \mathrm{ml}$ streptomycin, and maintained in a humidified atmosphere of $5 \%$ carbon dioxide $/ 95 \%$ air.

Rheumatoid synovial microvascular endothelial cells were isolated and cultured using modifications of immunomagnetic isolation techniques previously described in detail. ${ }^{18}$ Modifications of these techniques to improve cell yields and viability are detailed below. Rheumatoid synovial tissue was obtained at routine joint replacement surgery. The average age of the patients was 58.5 years, nine women and four men, the average disease duration prior to surgery was 7.5 years. Patients were not receiving non-steroidal anti-inflammatory drugs (NSAIDs) nor disease modifying agents immediately before surgery. Synovial membrane material was removed and minced into aid of a dissecting microscope, tissue pieces containing vessels with a lumen diameter $>150$ $\mu \mathrm{m}$ were removed and discarded. The remaining tissue pieces were incubated in $0.2 \%$ collagenase (CLS4, Worthington Biomedical Corporation, New Jersey) $/ 0.05 \%$ bovine testes hyaluronidase in Hanks's balanced salt solution for 60 minutes at $37^{\circ} \mathrm{C}$ before brief mechanical homogenisation. Undigested tissue pieces were removed from the homogenate by sequential filtration through $250 \mu \mathrm{m}, 100 \mu \mathrm{m}$ and $55 \mu \mathrm{m}$ nylon filters. The final filtrate was repeatedly passed through a flame polished siliconised glass pipette, to disaggregate small aggregates of cells into a single cell suspension. Cells were pelleted by centrifugation (400 $g$ for five minutes) before resuspension in $1 \mathrm{ml}$ of $\mathrm{PBS} / 1 \%$ BSA containing $1 \mu \mathrm{l}$ of anti-CD-31 antibody ( $1 \mathrm{mg} / \mathrm{ml}$ mouse $\operatorname{IgG}_{1}, \mathrm{R} \& \mathrm{D}$ Systems, Oxford) for 30 minutes on ice. Unbound antibody was removed by washing the cells three times in PBS $/ 1 \%$ BSA. A total cell count was performed and endothelial cell number was estimated as 5\% of the total. Endothelial cells were isolated by the addition of antimouse $\mathrm{IgG}_{1}$ coated paramagnetic Dynabeads (Dynal, Sweden) at a ratio of 3:1 (beads:endothelial cells) for 20 minutes in $1 \mathrm{ml} \mathrm{PBS} / 1 \% \mathrm{BSA}$ on ice. Endothelial cells bound to Dynabeads were retained in a permanent magnetic field while non-bound cells were removed by aspiration. This aspirate was retained for further endothelial cell isolation. The remaining bound endothelial cells were washed three times with $\mathrm{PBS} / 1 \% \mathrm{BSA}$ to remove contaminating cells. The procedure was repeated to harvest those endothelial cells that escaped the first isolation by the re-addition of Dynabeads to the aspirate, assuming the endothelial cell proportion to be $1 \%$ of the total. Anti-CD31 antibodies were used in preference to Ulex Europeaus agglutinin-1 (UEA-1) ${ }^{18}$ as although CD31 attached beads were found to be easier to dissociate from cells they offered better selectivity toward endothelial cells than UEA-1 coated beads, ensuring very high purity of sorted cell populations.

Isolated cells were cultured directly and usually shed attached beads after 96 hours in culture. Isolated SMEC were grown on fibronectin coated plastic or glass $\left(5 \mu \mathrm{g} / \mathrm{cm}^{2}\right)$ in Medium 199 supplemented with $15 \%$ v/v FCS and $15 \% \mathrm{v} / \mathrm{v}$ heat inactivated human $\mathrm{AB}$ serum with the addition of $20 \mathrm{ng} / \mathrm{ml}$ human recombinant epidermal growth factor (EGF) and 50 $\mu \mathrm{g} / \mathrm{ml}$ ECGS.

Human microvascular endothelial cells were isolated from subcutaneous adipose tissue (ADMEC) obtained from healthy donors undergoing breast reduction surgery or apronectomies. Subcutaneous adipose tissue (50-100 g) was minced and disaggregated by collagenase $(0.1 \%$ CLS4) for 60 minutes. ADMEC were isolated and cultured in a similar manner to the methods described in detail for SMEC. At confluence, SMEC and ADMEC cultures were maintained in HUVEC culture medium for 48 hours before assay. 
All isolated cells characterised as endothelial in origin displayed all of the following "endothelial" markers; contact inhibited growth with cells adopting a cobblestone morphology at confluence, von Willebrand factor expression, CD31 expression, metabolism of fluorochrome labelled acetylated low density lipoprotein (DiI-Ac-LDL) and the ability to differentiate into "vessel-like" tubes when cultured on the extracellular matrix substitute Matrige $^{20}$ (Collaborative Research, Massachusetts). All cells were used for experimentation at passage 3 and were $>95 \%$ homogeneous as assessed by the above criteria, the small minority of non-endothelial cells were not characterised further.

ADHESION MOLECULE CELL BASED ENZYME LINKED IMMUNOSORBENT ASSAY (CELISA) Endothelial cell adhesion molecule expression was assessed by a CELISA technique, based on methods developed by Wellicome et $a l^{21}$ Confluent monolayer endothelial cell cultures were stimulated with human recombinant TNF $\alpha$ (0-100 IU/ml) (Biological Standards Institute, Potter Bar, UK) for six hours before paraformaldehyde lysine periodate (PLP) fixation $\left(10\right.$ minutes at $\left.4^{\circ} \mathrm{C}\right)$. Adhesion molecule expression was assessed by a standard single layer ELISA technique using mouse antiVCAM-1 (clone 1.4c3), anti-E-selectin (clone 1.2b6) and anti-ICAM-1 (clone 6.5b5) primary antibodies (kindly provided by Dr D O Haskard, Hammersmith Hospital). PLP fixed cells were incubated in PBS containing $1 \%$ BSA for 20 minutes before the addition of primary antibodies. Cells were incubated in primary antibody solutions for 120 minutes at room temperature before gentle washing and addition of a biotinylated goat-antimouse immunoglobulin secondary antibody. The cells were further washed before the addition of an avidin/biotin/horseradish peroxidase solution (ABC complex) (Dako). The relative binding of the ABC complex was ascertained by the addition of a peroxide solution and the colourometric conversion of the chromagen 1,2-Phenylenediamine dihydrochloride at 492 nm using a Bio-tek EL12E multiwell plate reader (Anachem, Wycombe, England). Cell monolayers were inspected after the CELISA protocol detailed above, any wells containing damaged (incomplete) cell monolayers were ignored during subsequent data analysis. Adhesion molecule expression was directly compared between SMEC and HUVEC and then SMEC and ADMEC in separate experiments in which absolute optical density varied. To compare results obtained from these different experiments, results are expressed as a percentage of the optical density of SMEC stimulated with $100 \mathrm{IU} / \mathrm{ml} \mathrm{TNF} \alpha$.

The possibility that endotoxin contamination of the culture media additives might stimulate CAM expression was investigated by Limulus amoebocyte lysate assay. Results (not shown) quantified SMEC medium endotoxin levels as 200 -fold less than that required for HUVEC CAM activation. As an added precaution against differing culture medium inducing false positive adhesion molecule expression, SMEC, ADMEC and HUVEC were maintained in the same culture medium for 48 hours before assay.

VCAM-1 expression kinetics were assessed using a similar method. Cells were stimulated

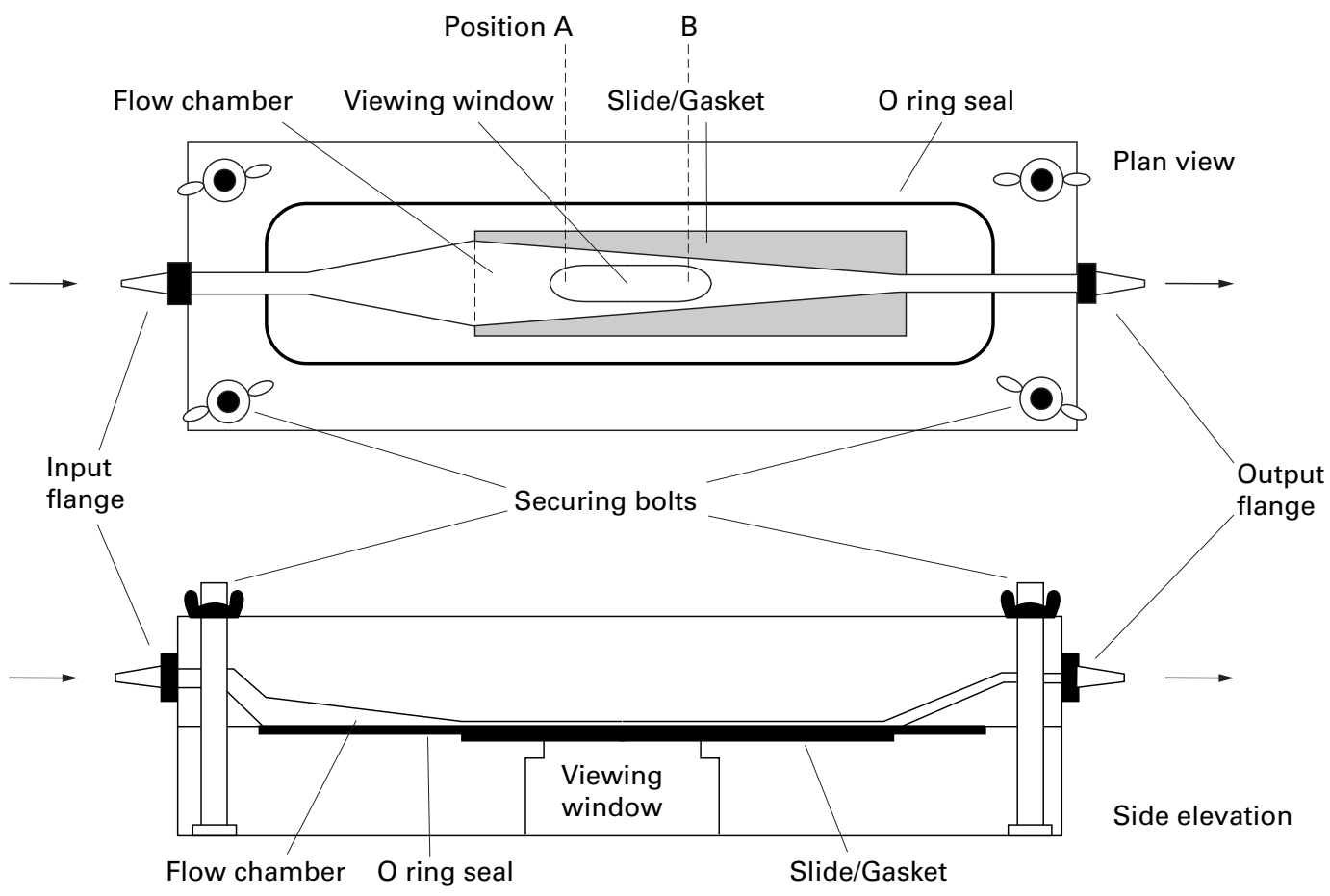

Flow chamber

Figure 1 Schematic representation of the parallel plate flow cell used. The convergence of the side walls of the cell increases the velocity of the perfusate as it travels through the cell. This increase in velocity permits measurements to be made on cells. exposed to an increasing wall shear stress in the same system without changing the mass flow volume. Wall shear stress at position $A\left(\tau_{A}\right)=2.4$ dynes $/ \mathrm{cm}^{2}$ and $\tau_{B}=4.0$ dynes $/ \mathrm{cm}^{2}$ assuming a volumetric flow rate of $0.916 \mathrm{~cm} / \mathrm{sec}(55 \mathrm{ml} / \mathrm{min})$. 

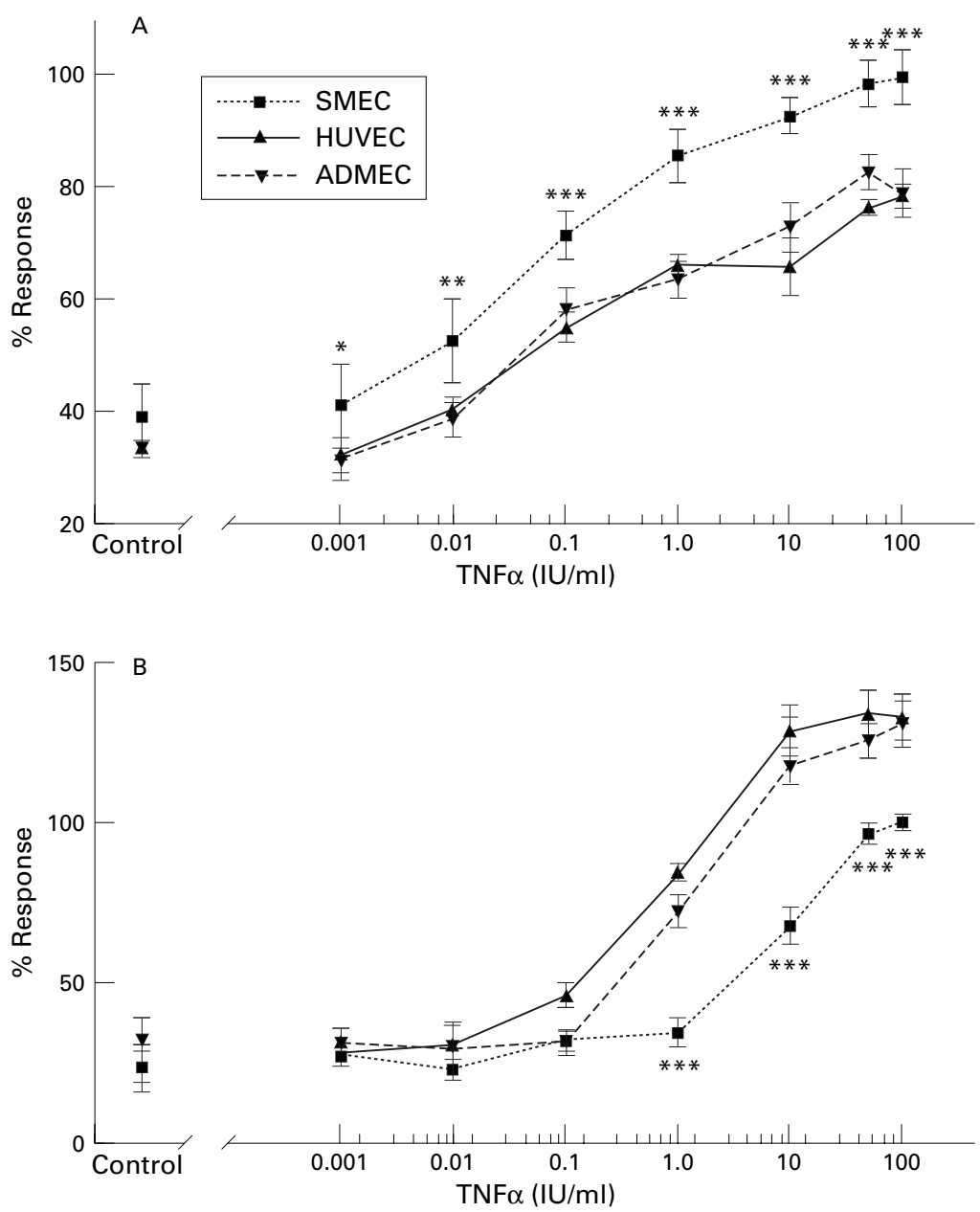

Figure 2 (A) HUVEC, ADMEC and SMEC monolayers were stimulated TNFa (0-100 $I U / \mathrm{ml}$ ) for six hours before assessment of E-selectin expression. Results are normalised as percentages of the optical density observed in SMEC cultures stimulated with $100 \mathrm{IU} / \mathrm{ml}$ TNFa and depict 95\% confidence intervals for the mean response. E-selectin expression by SMEC was compared with both HUVEC and ADMEC. SMEC display significantly $\left(p<0.05^{\star}, p<0.01^{\star \star}, p<0.001^{\star \star \star}\right)$ higher E-selectin expression than HUVEC or $A D M E C$ at all concentrations of TNFa, $(n=3)$. (B) HUVEC, ADMEC and SMEC monolayers were pre-incubated with $\mathrm{TNF} a(0-100 \mathrm{IU} / \mathrm{ml})$ for six hours before assessment of VCAM-1 expression. Results are normalised as percentages of the optical density observed in SMEC cultures stimulated with $100 \mathrm{IU} / \mathrm{ml}$ TNFa and depict $95 \%$ confidence intervals for the mean response. VCAM-1 expression by HUVEC and ADMEC was not significantly different. SMEC display significantly $\left(p<0.001^{\star \star \star}\right)$ lower VCAM-1 expression than HUVEC or ADMEC at concentrations of TNFa in excess of $1 \mathrm{IU} / \mathrm{ml}$, $(n=3)$.

with $\mathrm{TNF} \alpha(50 \mathrm{IU} / \mathrm{ml})$ at two hour intervals for 0-24 hours, before fixation and assessment of VCAM-1 surface expression.

\section{LEUCOCYTE ISOLATION}

PMN neutrophils were isolated from whole blood, obtained by venopuncture from healthy volunteers, by density dependent centrifugation over Histopaque $(\rho=1.077 \mathrm{~g} / \mathrm{ml})$, by the methods of Bøyum..$^{22}$ Isolated cells were characterised as neutrophils by the presence of multi-lobed nuclei in greater than $98 \%$ of the cells.

$\mathrm{T}$ lymphocytes were isolated from similar blood samples by the following method. Total mononuclear cells were isolated by density dependent centrifugation. $T$ lymphocytes were obtained from this cell fraction by purging of $B$ lymphocytes and monocytes. Monocytes were removed by adhesion to tissue culture plastic flasks when incubated for 30 minutes at $37^{\circ} \mathrm{C}$. B lymphocytes were removed by positive immunomagnetic selection using anti-CD19 coated Dynabeads. After monocyte purging the isolated cells were counted and B cell proportions were estimated as $30 \%$ of the total, antiCD19 coated Dynabeads were incubated with the B lymphocytes at a ratio of $20: 1$ for 30 minutes at $4^{\circ} \mathrm{C}$. After incubation, B lymphocytes bound to Dynabeads were retained in a permanent magnetic field while $\mathrm{T}$ lymphocytes were removed by aspiration. $\mathrm{T}$ cell purity was generally greater than $91 \%$ as assessed by anti-CD2 (Dako Ltd, High Wycombe, UK) FACS analysis. The proportion of CD45RO+ cells in this population was assessed in a similar manner using FITC conjugated anti-CD45RO+ antibody (Dako).

\section{STATIC LEUCOCYTE ADHESION ASSAYS}

Static leucocyte adhesion assays were performed according to methods devised by Cavender. ${ }^{23}$ Isolated leucocytes were labelled with ${ }^{51} \mathrm{Chro}-$ mium $\left(\mathrm{Na} \mathrm{CrO}_{4}\right)\left(300 \mu \mathrm{Ci} / 1 \times 10^{7}\right.$ cells $)$ for 90 minutes at $37^{\circ} \mathrm{C}$. These cells were added to endothelial cell monolayers grown in fibronectin $\left(5 \mu \mathrm{g} / \mathrm{cm}^{2}\right)$ coated 96 well plates that had been previously stimulated for six hours with $0-100$ $\mathrm{IU} / \mathrm{ml} \mathrm{TNF} \alpha$ or $0-1000 \mathrm{IU} / \mathrm{ml} \mathrm{IL} 1$. After incubation for 30 minutes at $37^{\circ} \mathrm{C}$ in $\mathrm{M} 199 / 10 \%$ FCS unbound cells were removed by aspiration. The percentage of bound leucocytes was calculated by lysing endothelial cells and leucocytes $\left(1 \%\right.$ Triton $\mathrm{X}-100$ overnight at $\left.4^{\circ} \mathrm{C}\right)$ and gammacounting the lysate using a Beckman 5500 gammacounter.

Percentages were calculated as:

$\%$ leucocytes bound $=\frac{\text { Counts per minute in } 100 \mu \mathrm{l}}{\text { Counts per minute in } 100 \mu \mathrm{l} \text { original PMS suspension }} \times 100$

Antibody neutralisation experiments were conducted with $\mathrm{TNF} \alpha$ stimulated endothelial cells that had been exposed to anti-ICAM-1 antibodies (50 $\mu \mathrm{g} / \mathrm{ml}$, clone BBIG-I1) (R\&D Systems, Abingdon, UK) for 30 minutes before the addition of leucocytes as detailed above. Experiments were conducted a minimum of three times using a minimum of three replicate wells in each multiwell plate.

DYNAMIC LEUCOCYTE BINDING ASSAYS

Dynamic leucocyte binding assays were performed using a tapering width parallel plate flow cell (fig 1). Endothelial cell monolayers were grown to confluence on fibronectin coated $\left(5 \mu \mathrm{g} / \mathrm{cm}^{2}\right)$ glass slides that were incorporated as one wall of the flow cell. Because of the decreasing width of the flow chamber, endothelial cells at different positions within the flow cell experienced a linearly increasing rate of shear $\left(0.6-5.2\right.$ dynes $\left./ \mathrm{cm}^{2}\right)$ as fluid passed through the chamber at a constant flow rate. Endothelial cells and circulating leucocytes were viewed using an inverted phase contrast microscope. The leucocyte circulating medium was warmed to $37^{\circ} \mathrm{C}$ by a countercurrent heat exchanger immediately upstream of the chamber.

Endothelial cell monolayers were stimulated with $\mathrm{TNF} \alpha(100 \mathrm{IU} / \mathrm{ml})$ for six hours before use. After stimulation, monolayers were washed with three changes of Dulbecco's modified Eagles medium (DMEM) before 

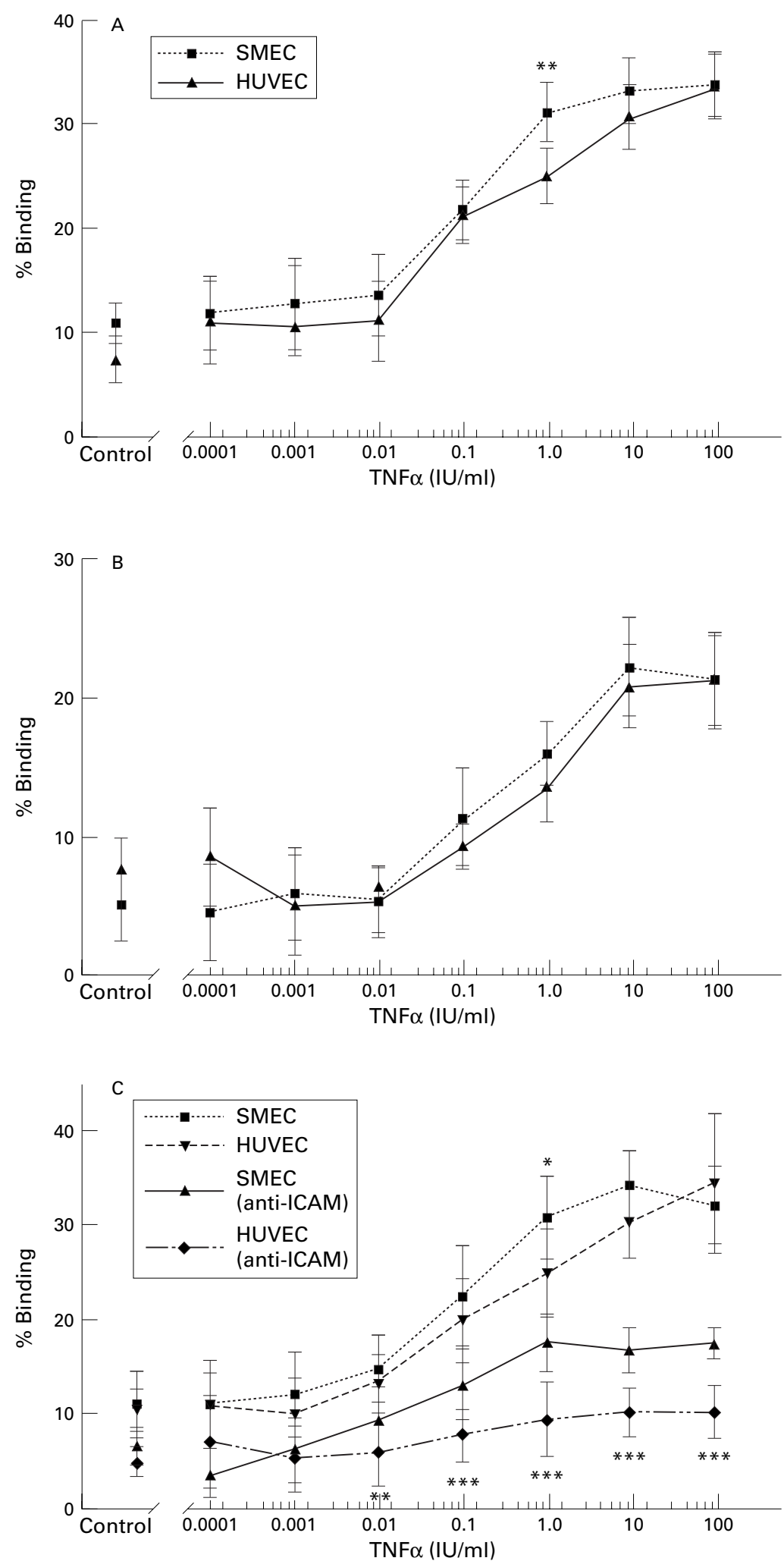

Figure 3 (A) Neutrophil adhesion to HUVEC and SMEC monolayers pre-incubated with TNFa (0-100 IU/ml). Results show mean binding of neutrophils as a percentage of the initial number added and depict $95 \%$ confidence intervals for the mean binding. SMEC occasionally, but not consistently, bind significantly $\left(p<0.01^{\star *}\right)$ higher numbers of neutrophils than HUVEC $(n=5)$. (B) T lymphocyte adhesion to HUVEC and SMEC monolayers pre-incubated with TNFa $(0-100 \mathrm{IU} / \mathrm{ml})$. Results are expressed as the mean percentage binding of the original number of lymphocytes added and depict $95 \%$ confidence intervals for the mean binding. No significant differences were observed between cell types $(n=5)$. (C) Comparison of static PMN adhesion to $T N F a(0-100 \mathrm{IU} / \mathrm{ml})$ stimulated endothelial cell monolayers. Results show mean binding of neutrophils as a percentage of the initial number added and depict 95\% confidence intervals for the mean binding. Results indicate differences in neutrophil binding to the two endothelial cell types before the addition of anti-ICAM-1 antibody $(50 \mu \mathrm{g} / \mathrm{ml})$, rarely reaches significance $\left(p<0.05^{\star}\right)$. However, in the presence of anti-ICAM-1 antibody SMEC are capable of binding significantly $\left(p<0.05^{\star}, p<0.01^{\star \star}, p<0.001^{\star \star \star}\right)$ more PMN than similarly treated HUVEC at a number of TNFa concentrations $(n=3)$. placement in the flow cell. Isolated leucocytes $\left(1 \times 10^{7}\right.$ cells $)$ were allowed to circulate for 30 minutes $(25 \mathrm{ml} / \mathrm{min})$ before the endothelial cell slides were fixed in PLP fixative for 10 minutes. The number of adherent leucocytes per $\mathrm{mm}^{2}$ were counted at positions on the slides that experienced wall shear rates of 2.4 and 4.0 dynes $/ \mathrm{cm}^{2}$.

The subclasses of adherent $\mathrm{T}$ lymphocytes were analysed by direct immunofluorescence using FITC conjugated mouse antiCD45RO+ (Serotec, Kidlington, England) antibodies. An inverted fluorescence phase contrast microscope (Diaphot II, Nikon) was used to count fluorescent lymphocytes that were expressed as a percentage of the total per field of view, revealed by phase contrast.

\section{STATISTICS ANALYSIS AND PRESENTATION OF} RESULTS

Adhesion molecule expression is presented as percentages of SMEC maximal responses as ascertained by measurement of CELISA optical densities. Changes in optical densities are assumed to be directly proportional to adhesion molecule expression over the range studied, however as this cannot be directly tested as $\mathrm{EC}_{50}$ values for the effects of $\mathrm{TNF} \alpha$ have not been calculated. The ' $n$ ' numbers presented in figure legends represent the number of individual patient cell populations used to calculate the results. Different patient cell populations were used throughout the course of the experimental work presented.

Results represent mean with $95 \%$ confidence intervals assuming normally distributed percentage response at each TNF concentration and using a separate variance estimate at each concentration. Optical density and adherent cell number data were compared at individual cytokine concentrations and shear stress points by ANOVA and Bonferroni posttest analysis using GraphPad Prism 3.0 for Windows 95 (GraphPad Software Inc, San Diego CA). We used the equation built into the program with each replicate value being entered as a separate value. Individual significance thresholds are shown on each figure.

\section{Results}

SMEC, ADMEC and HUVEC all displayed the following characteristic endothelial cell markers; contact inhibited cobblestone morphology at confluence, discrete granular immunolocalisation of von Willebrand factor (vWf), metabolism of fluorochrome labelled acetylated low density lipoprotein and expression of E-selectin. All cells differentiated into capillary-like structures within 4-12 hours when grown on substrates coated with the basement membrane derivative Matrigel. The microvascular nature of isolated SMEC and ADMEC was guaranteed during the initial tissue dissection by discarding tissue fragments containing vessels with a lumen diameter $>150$ $\mu \mathrm{m}$.

We have previously demonstrated that IL1 stimulated SMEC display increased E-selectin expression in comparison with similarly treated HUVEC cultures. ${ }^{18}$ This study extends these 

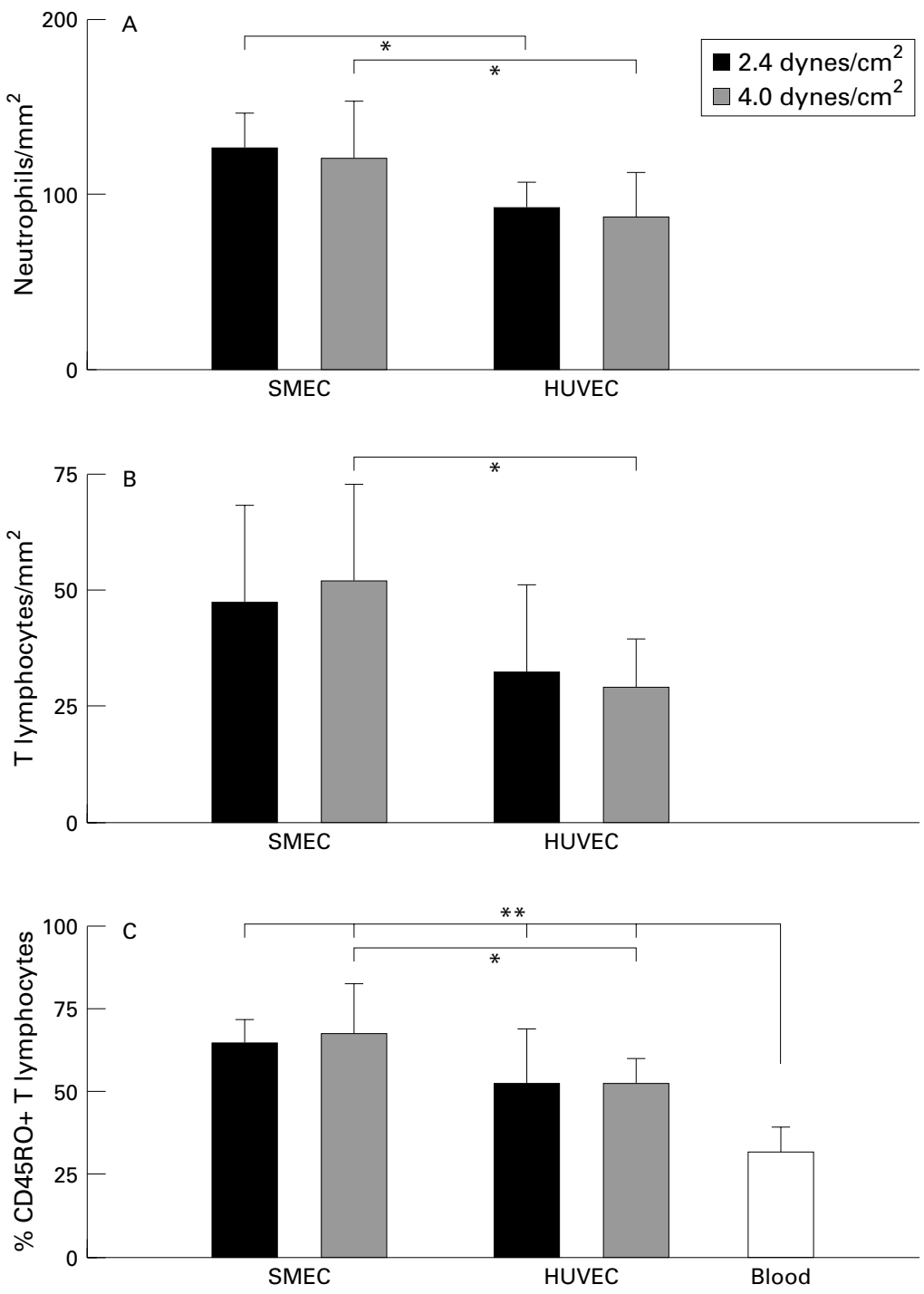

Figure 4 Adhesion of (A) peripheral blood neutrophils and (B) T lymphocytes to SMEC and HUVEC monolayers pre-stimulated with TNFa (50 IU/ml) for five hours. The cell counts represents the mean number of leucocytes (per $\mathrm{mm}^{2}$ ) attached to the endothelial monolayers, after 30 minutes of continuous circulation, at points in the flow chamber where wall shear rates were calculated at 2.4 and 4.0 dynes $/ \mathrm{cm}^{2}$ respectively and depict $95 \%$ confidence intervals for the mean response. SMEC monolayers bound significantly $\left(p<0.05^{\star}\right)$ higher numbers of both neutrophils at both 2.4 and 4.0 dynes $/ \mathrm{cm}^{2}$ in comparison with HUVEC at the same rates of shear. Differences in T lymphocytes adhesion to SMEC in comparison with HUVEC were only significant $\left(p<0.05^{\star}\right)$ at higher $(4.0$ dynes $\left./ \mathrm{cm}^{2}\right)$ rates of shear $(n=3)$. (C) Immunohistochemical analysis of adherent $T$ lymphocyte phenotype and initial proportions in healthy peripheral blood. Results are expressed as the proportion of cells bearing a CD45RO+ phenotype as a percentage of the total and depict $95 \%$ confidence intervals for the mean response. Cell populations adherent to both SMEC and HUVEC monolayers at both 2.4 and 4.0 dynes/ $/ \mathrm{cm}^{2}$ display a significant $\left(p<0.01^{\star \star}\right)$ increase in the proportions of CD45RO+ cells in comparison with peripheral blood. SMEC also display a significantly $\left(p<0.05^{\star}\right)$ increased capacity to bind such cells in comparison to HUVEC at higher $\left(4.0\right.$ dynes $\left./ \mathrm{cm}^{2}\right)$ rates of shear $(n=3)$.

observations by comparing E-selectin expression by SMEC to human microvascular endothelial cells derived from subcutaneous adipose tissue. Results demonstrate that ADMEC and HUVEC express similar levels of E-selectin after TNF $\alpha$ stimulation and confirm an approximately $30 \%$ increase in maximal expression by SMEC in comparison with either ADMEC or HUVEC (fig 2A). Stimulation of SMEC, ADMEC or HUVEC with IL1 (results not shown) elicited similar responses to those observed after $\mathrm{TNF} \alpha$ treatment. Stimulation of each endothelial cell type with $50 \mathrm{IU} / \mathrm{ml}$ of $\mathrm{TNF} \alpha$ generally induced maximal VCAM-1. However, unlike E-selectin expression, VCAM-1 expression by SMEC was significantly less sensitive to $\mathrm{TNF} \alpha$ stimulation than HUVEC or ADMEC (fig 2B). Comparison of ICAM-1 expression on ADMEC extended previous observations that showed no significant difference between basal or TNF $\alpha$ induced expression in SMEC and HUVEC. ${ }^{18}$ None of the cell types displayed significant basal expression $(0.85 \mathrm{IU} / \mathrm{ml}$ average) and maximal ICAM-1 expression was not significantly different after $\mathrm{TNF} \alpha$ stimulation.

We hypothesised that as dose responses to $\mathrm{TNF} \alpha$ were measured at one time point (six hours of stimulation), differences between cytokine stimulated VCAM-1 and E-selectin expression in SMEC in comparison with ADMEC or HUVEC may have been attributable to differences in the time required for the respective cell types to display maximal surface expression. However, this hypothesis was not supported by the results of a time course in which endothelial cells were stimulated with 50 $\mathrm{IU} / \mathrm{ml} \mathrm{TNF} \alpha$ for periods of between 0 and 24 hours that demonstrated that maximal E-selectin and VCAM-1 expression occurred between five and nine hours in all three cell types and SMEC consistently expressed lower VCAM-1 and higher E-selectin levels at all time points. Also, while VCAM-1 expression in HUVEC and ADMEC remained near maximal levels for periods up to 24 hours SMEC expression decayed slowly beyond 10 hours (results not shown)

HUVEC and ADMEC demonstrated very similar adhesion molecule expression profiles in response to $\mathrm{TNF} \alpha$. Therefore, because of the ease of isolation and lower cost associated with the isolation and culture of HUVEC, these cells alone were used to compare leucocyte adhesion to SMEC. We predicted that differences between the ability of proinflammatory cytokines to induce adhesion molecule expression in isolated SMEC and HUVEC would result in differences in the ability of these cells to bind leucocytes.

Analysis of neutrophil (fig 3A) and $\mathrm{T}$ lymphocyte (fig 3B) binding to SMEC and HUVEC in static assays revealed little difference between the level of adhesion (number of leucocytes binding) to either endothelial cell type after stimulation of the endothelial cells with $\mathrm{TNF} \alpha(0-100 \mathrm{IU} / \mathrm{ml})$. In general, $\mathrm{TNF} \alpha$ stimulated SMEC had a tendency to bind more neutrophils and $\mathrm{T}$ lymphocytes than similarly treated HUVEC, however this trend did not exhibit consistent statistical significance.

The possibility that ICAM-1/integrin interactions were masking differences in E-selectin and VCAM-1 mediated cell adhesion was assessed in two ways. Firstly, static leucocyte adhesion assays were performed using stimulated endothelial cell monolayers pre-treated with neutralising antibodies to ICAM-1 and secondly, leucocyte adhesion was assessed using a physiologically relevant dynamic assay.

$\mathrm{TNF} \alpha$ stimulated endothelial cells were incubated with a neutralising antibody to ICAM-1 for 30 minutes before the addition of leucocytes. Results demonstrated, that while the overall number of neutrophils adhering was 
significantly decreased, adhesion of neutrophils to $\mathrm{TNF} \alpha$ stimulated SMEC was significantly higher than HUVEC treated in a similar manner (fig 3C).

Dynamic leucocyte adhesion assays were designed to inhibit imunoglobulin/integrin mediated adhesion by subjecting leucocyte/ endothelial cell interactions to a shear stress in excess of 2 dynes $/ \mathrm{cm}^{2}$

Results of dynamic leucocyte adhesion assays demonstrated that $\mathrm{TNF} \alpha(100 \mathrm{IU} / \mathrm{ml})$ stimulated SMEC monolayers were capable of binding significantly $(\mathrm{p}<0.05)$ greater numbers of neutrophils than HUVEC monolayer when exposed to shear stresses of 2.4 and 4.0 dynes/ $\mathrm{cm}^{2}$ (fig 4A). A similar phenomenon was observed with $\mathrm{T}$ lymphocyte adhesion when exposed to a shear stresses of 4.0 dynes $/ \mathrm{cm}^{2}$ (fig 4B).

Immunocytochemical quantification of $\mathrm{CD} 45 \mathrm{RO}+\mathrm{T}$ lymphocytes adhering to endothelial cell monolayers demonstrated that both SMEC and HUVEC monolayers supported significantly $(\mathrm{p}<0.05)$ increased binding of CD45RO+ $\mathrm{T}$ lymphocytes when exposed to rates of shear of 2.4 and 4.0 dynes $/ \mathrm{cm}^{2}$ in comparison with $\mathrm{CD} 45 \mathrm{RO}+$ cell proportions found in the initial $\mathrm{T}$ cell isolate. In addition CD45RO+ cells comprised up to $69 \%$ of the $\mathrm{T}$ lymphocyte populations adherent to $\mathrm{TNF} \alpha$ stimulated SMEC monolayers subjected to a wall shear stress of 4.0 dynes $/ \mathrm{cm}^{2}$, this proportion was significantly $(\mathrm{p}<0.001)$ higher than that of CD45RO+ cells in the initial $\mathrm{T}$ lymphocyte isolate (32\%) (fig $4 \mathrm{C}$ ).

\section{Discussion}

The aims of this study were to examine the ability of $\mathrm{TNF} \alpha$, to induce VCAM-1, E-selectin and ICAM-1 expression and leucocyte adhesion to endothelial cells isolated from rheumatoid synovial microvasculature in comparison with endothelial cells isolated from human umbilical vein or the microvasculature of human subcutaneous adipose tissue.

$\mathrm{TNF} \alpha$ stimulated E-selectin expression by SMEC, ADMEC and HUVEC in this study is similar to results of IL1 stimulated expression in our earlier investigations ${ }^{18}$ and is consistent with a study by To et $a l^{26}$ that demonstrated increased expression of E-selectin by $\mathrm{TNF} \alpha$ stimulated SMEC in comparison with either HUVEC or microvascular endothelial cells derived from neonatal foreskin. A possible explanation of the increased cytokine induced E-selectin expression by SMEC has been highlighted by the recent observations of Chen et al ${ }^{27}$ that endothelial cell gene expression is not only positively regulated but that a further degree of control is afforded by the actions of an, as yet, unidentified repressor protein. It is therefore possible that the increased E-selectin expression by SMEC, observed both in vitro and in vivo may be reflect a defect in this repressor protein expression, however this hypothesis requires further study.

VCAM-1 expression by SMEC in this study was significantly less sensitive to $\mathrm{TNF} \alpha$ stimulation than that of HUVEC or ADMEC. Time course studies demonstrated that this result is not because of differences in the kinetics of maximal VCAM-1 induction by SMEC in response to $\mathrm{TNF} \alpha$ in comparison with HUVEC or ADMEC. Our present results are however inconsistent with the results of To and colleagues that failed to show any difference in VCAM-1 expression between the endothelial cells studied. To et al demonstrated that although the average E-selectin expression by SMEC was higher than in the other endothelial cell types, when individual cell E-selectin expression was analysed by flow cytometry certain cells displayed very low expression. This observation may be explained by either questioning the purity of SMEC cultures used by To or alternatively, if true heterogeneity does exist in SMEC E-selectin expression, similar heterogeneity might be expected in VCAM-1 expression. It is possible that in this study, during cell isolation and culture, we have unwittingly selected for low VCAM-1expressing SMEC populations. However, while selection and culture methods for ADMEC and SMEC were identical VCAM-1 expression was not. Marui and colleagues have suggested that the transcription of E-selectin and VCAM-1 may be regulated in a similar manner by the oxidant sensitive transcription factor $\mathrm{NF} \kappa \mathrm{B} .{ }^{28}$ Our results suggest that $\mathrm{TNF} \alpha$ (or IL1, results not shown) induced VCAM-1 and E-selectin expression by SMEC are differentially regulated and support evidence to suggest that $\mathrm{NF \kappa B}$ is not the sole transcriptional controlling mechanism for either gene. ${ }^{29} 30$ Reports that IL4 and TNF $\alpha$ act in synergy to both increase and prolong VCAM-1 surface expression in HUVEC $^{31}$ remain to be tested in SMEC. The relative insensitivity of VCAM-1 expression by SMEC in vitro may, however, explain immunohistochemical findings that rheumatoid synovial microvessels, unlike the microvasculature in other inflamed tissues, seldom express high levels of VCAM-1. ${ }^{12} \mathrm{Al}-$ though synovial microvessels display little cell surface associated VCAM-1, increased levels of soluble VCAM-1 (VCAM-s) have been demonstrated in the serum of rheumatoid arthritis patients. ${ }^{32}$ The possibility that the relatively low VCAM-1 expression by cytokine stimulated SMEC is attributable to rapid cleavage from the cell surface remains to be tested.

Analysis of neutrophil and T lymphocyte binding to $\mathrm{TNF} \alpha$ stimulated SMEC and HUVEC monolayers in static binding assays revealed little difference in the levels of adhesion (numbers of leucocytes bound) when comparing endothelial cells types. While this result supports previous studies comparing peripheral blood $\mathrm{T}$ lymphocyte adhesion to cytokine treated endothelial cells derived from human dermal tissue (DMVEC) and HUVEC, ${ }^{33}$ it is inconsistent with reports that neutrophils have a tendency to adhere in higher numbers to C5a stimulated human omental fat derived microvascular endothelial cells than to HUVEC. ${ }^{34}$ In addition, results of our static cell adhesion assays failed to support the hypothesis that increased SMEC E-selectin expression would lead to increased leucocyte adhesion. Current dogma suggests that leucocyte 
adhesion and diapedesis is a multi-step process involving the sequential action of several families of cellular adhesion molecules. ${ }^{35}{ }^{36}$ Initially, shear independent selectins mediate the slowing of circulating leucocytes, allowing shear dependent bonds to be formed between members of the immunoglobulin type adhesion molecules and members of the $\beta_{1}$ and $\beta_{2}$ integrin families when the effective wall shear stress has fallen below 2.0 dynes $/ \mathrm{cm}^{2}{ }^{24}$ Therefore, adhesion during sedimentation in vitro may be predominately mediated by shear rate dependent ICAM- $1 / \beta_{2}$ integrin interactions. To determine whether ICAM- $1 / \beta_{2}$ integrin mediated adhesion was masking differences in selectin mediated adhesion in static assay systems, static neutrophil adhesion assays were repeated with the inclusion of a neutralising antibody to ICAM-1. Results demonstrated that while the addition of anti-ICAM-1 antibodies significantly reduced the number of neutrophils adhering to both SMEC or HUVEC monolayers, TNF $\alpha$ and anti-ICAM-1 treated SMEC were capable of supporting significantly higher levels of neutrophil binding than HUVEC treated in a similar manner.

To study the effects of sheer stress on human leucocyte/endothelial cell interactions we developed a parallel plate flow cell that permitted the growth of isolated endothelial cells on one optically clear surface. Results demonstrated that $\mathrm{TNF} \alpha$ stimulated SMEC were capable of binding higher numbers of neutrophils and $\mathrm{T}$ lymphocytes than HUVEC when exposed to shear rates of $>2.0$ dynes $/ \mathrm{cm}^{2}$. Adhesion of both neutrophils and $\mathrm{T}$ lymphocytes to SMEC, in comparison with HUVEC correlates well with increased E-selectin expression by cytokine stimulated SMEC, however the absolute contribution of E-selectin to leucocyte adhesion, as confirmed by antibody blockade, was not tested in this study. Recently it has been recognised that the modulation of shear independent leucocyte adhesion is not a property unique to selectins. Under conditions of flow in vitro, peripheral blood derived $T$ lymphocytes have been shown to both roll and firmly adhere to VCAM-1 transfected COS cells, ${ }^{36}$ processes that could be abolished by the addition of anti-VCAM-1 or anti-VLA-4 antibodies to the system. These results are intriguing but are unlikely to explain the increased $\mathrm{T}$ lymphocyte adhesion to SMEC because of the low levels of surface expression of VCAM-1 on these cells. These observations do not, however, rule out a role for VLA-4 in mediating lymphocyte accumulation in vivo where vascular derangement may expose extracellular matrix fibronectin, providing an alternative ligand for VLA- $4 .^{37}$ Alternatively, the possibility that $\beta_{1}$ integrin interaction with the mucosal addressin MAdCAM-1 may mediate leucocyte rolling ${ }^{38}$ on SMEC remains to be tested.

$\mathrm{T}$ lymphocytes bearing a CD45R0+ memory phenotype comprise approximately one third of the circulating lymphocyte pool both in health and rheumatoid disease, however, selective recruitment of this class of $\mathrm{T}$ lymphocyte within the rheumatoid synovium can increase the proportion twofold. ${ }^{12} 39$ Analy- sis of the $\mathrm{T}$ lymphocytes that adhered to SMEC and HUVEC during dynamic binding assays revealed as significant enrichment in the proportion of CD45RO+ cells in comparison to $\mathrm{T}$ cell populations before adhesion. Selectin ligands include E-selectin ligand-1 (ESL-1), P-selectin glycoprotein ligand-1 (PSGL-1) a post-translational modification of PSGL-1 known as cutaneous lymphocyte associated antigen (CLA), ${ }^{39}$ together with Sialyl Lewis $\mathrm{x}$ and a $\left(\mathrm{SLe}^{\mathrm{x}}\right.$ and $\left.\mathrm{Sle}^{\mathrm{a}}\right)$. E-selectin transfected COS cells are capable of binding skin homing memory $\mathrm{T}$ lymphocytes, ${ }^{10}$ a property not shared by other lymphocyte populations, via E-selectin interaction with the CLA. While it is tempting to suggest E-selectin/CLA interactions may explain our results in vitro, studies have demonstrated a relatively low number of CLA+ve T lymphocytes in rheumatoid synovial tissue sections in comparison with skin sections obtained from patients suffering from psoriatic arthritis. ${ }^{40}$ The expression of CLA on migrating $\mathrm{T}$ lymphocytes may however be a transient phenomenon. The possibility that $\mathrm{T}$ lymphocytes adhere to activated SMEC via the ligand ESL-1 remains a possibility, however, recent studies have demonstrated that only $20-30 \%$ of CLA +ve lymphocytes co-express ESL-1. ${ }^{41}$

In conclusion, the results demonstrate that rheumatoid synovial endothelial cell VCAM-1 expression in vitro is relatively insensitive to cytokine $(\mathrm{TNF} \alpha)$ stimulation in comparison to HUVEC or microvasculature derived ADMEC. While these results may help to explain previous observations detailing the immunohistochemical absence of VCAM-1 expression in rheumatoid synovial microvasculature in conjunction with increased levels of pro-inflammatory cytokines in rheumatoid synovial fluid, they do not provide an explanation of the massive leucocyte accumulation generally found within rheumatoid synovial tissue. In contrast, cytokine stimulation of SMEC monolayers in vitro led to increased adhesion of leucocytes at physiologically relevant flow (shear) rates in comparison to HUVEC. The shear independent nature of such adhesion strongly supports a role for selectins in increasing leucocyte adhesion to SMEC. In particular, the selective adhesion of CD45RO+ T lymphocytes to SMEC monolayers under conditions of flow may explain patterns of $\mathrm{T}$ cell accumulation in vivo. Although not directly tested, observations of increased E-selectin expression by cytokine stimulated SMEC, in comparison with ADMEC or HUVEC, seem to correlate well with increased leucocyte, particularly CD45RO+ T lymphocyte adhesion to SMEC monolayers. We believe that the evidence presented here supports the hypothesis in which cell specific alteration of mechanisms regulating the expression of cellular adhesion molecules, specifically selectins, by the microvasculature of the rheumatoid synovium facilitates selective leucocyte recruitment and may play an important part in maintaining the chronic synovitis associated with rheumatoid arthritis. 
The authors are grateful for the generous gift of anti-CD106 (clone 1.4c3), anti E-selectin (clone 1.2b6) and anti-ICAM-1 (clone 6.5b5) antibodies form Dr D O Haskard, Hammersmith Hospital, London, together with the assistance of Mrs M Wes and Dr G Scott in the provision of synovial membrane tissue samples.

1 Kobayashi I, Ziff M. Electron microscopic studies of the cartilage-pannus junction in rheumatoid arthritis. Arthritis Rheum 1975;18:475-83.

2 Duke OL, Hobbs S, Panayi GS, Poulter LW, Rasker JJ, Janossy G. A combined immunohistological and histochemical analysis of lymphocyte and macrophage subpopulations in the rheumatoid nodule. Clin Exp Immuno 1984;56:239-46.

3 Cush JJ, Lipsky PE. Dual immunofluorescence analysis of lymphocyte subsets eluted from rheumatoid synovium. FASEB J 1990;4:1855-60

4 Pober JS, Cotran RS. What can be learned from the expression of endothelial cell adhesion molecules in tissues. Lab Invest 1991;64:301-5.

5 Norris P, Poston RN, Thomas DS, Thornhill M, Hawk J, Haskard DO. The expression of endothelial leucocyte adhesion molecule-1 (ELAM-1), intercellular adhesio molecule-1, (CD54) and vascular cell adhesion molecule-1 (CD106) in experimental cutaneous inflammation: a comparison to ultraviolet B erythema and delayed hypersensitivity. J Invest Dermatol 1991;96:763-70.

6 Munro JM, Pober JS, Cotran RS. Recruitment of neutrophils in the local endotoxin response: association with de novo endothelial expression of endothelial leukocyte adhesion molecule-1. Lab Invest 1991;64:295-9.

7 Cotran RS, Gimbrone M, Bevilacqua MP, Mendick DL, Pober JS. Induction and detection of a human endothelial activation antigen in vivo. Exp Med 1986:164:661-6.

8 Waldorf HA, Walsh J, Schechter NM, Murphy GF. Early cellular events in evolving cutaneous delayed hypersensitivity in humans. Am J Pathol 1991;138:477-86.

Graber N, Gopal TV, Wilson D, Beall LB, Polte T, Newman W. T-cells bind to cytokine-activated endothelial cells via novel inducible sialoglycoprotein and ELAM-1. J Immuno 1990;145:819-30.

10 Picker LJ, Kishimoto TK, Smith CW, Warnock RA, Butcher EC. ELAM-1 is an adhesion molecule for skin homing T-cells. Nature 1991;349:796-9.

11 Shimizu Y, Shaw S, Graber N, Gopal VT, Horgan KJ, van Seventer GA, et al. Activation-independant binding of human memory T-cells to adhesion molecule ELAM-1. Nature 1991;349:799-802.

12 Postigo AA, Garcia Vincña R, Diaz-Gonzalez F, Arroyo AG, De Landázuri MO, Chi-Rosso G, et al. Increased binding of synovial T-lymphocytes from rheumatoid arthritis to endothelial-leukocyte adhesion molecule-1 (ELAM-1) and vascular cell adhesion molecule-1 (CD106). J Clin Invest 1992;89:1445-52.

13 Carlos T, Kovach N, Schwartz B, Rosa M, Newman B, Wayner $\mathrm{E}$, et al. Human monocytes bind to two cytokine-induced adhesive ligands on cultured human endothelial cells: endothelial-leukocyte adhesion molecule-1 and vascular cell adhesion molecule-1.Blood 1991;77:2266-71.

14 Sriramarao P, von Andrian UH, Butcher EC, Bourdon MA, Broide DH. L-selectin and very late antigen-4 integrin promote eosinophil rolling at physiological shear rates in vivo. J Immunol 1994;153:4238-46.

15 Koch AE, Burrows JC, Haines GK, Carlos TM, Harlan JM, Leibovich SJ. Immunolocalization of endothelial and leukocyte adhesion molecules in human rheumatoid and leukocyte adhesion molecules in human rheumatoid and

6 Lo SK, Lee S, Ramos RA, Lobb R, Rosa M, Rosso-Chi G, et al. Endothelial-leukocyte adhesion molecule-1 stimulates the adhesive activity of leukocyte integrin CR3 (CD11b/ CD18, Mac-1, $\alpha \mathrm{m} \beta 2$ ) on human neutrophils. J Exp Med 1991;170:1493-500.

17 Oppenheimer-Marks N, Davis LS, Bogue DT, Ramberg J, Lipsky PE. Differential utilization of CD54 and CD106 during the adhesion and transendothelial migration of human T lymphocytes. J Immunol 1991;147:2913-21.

18 Abbot SE, Kaul A, Stevens CR, Blake DR. Isolation and culture of synovial microvascular endothelial cells: Characterisation and assessment of adhesion molecule expression. Arthritis Rheum 1992;35:401-6.

19 Jaffe EA, Nachman RL, Becker CG, Minick CR. Culture of human endothelial cells derived from umbilical veins. J Clin Invest 1973;52:2745-56.
20 McGuire PG, Orkin RW. Isolation of rat aortic endothelial cells by primary explant techniques and their phenotypic modulation by defined substrata. Lab Invest 1987;57:94 105 .

21 Wellicome S, Thornhill M, Pitzalis C, Thomas DS, Lanchbury JS, Panayi GS, et al. A monoclonal antibody that detects a novel antigen on endothelial cells that is induced by tumour necrosis factor, interleukin-1 and lipopolysacharide. J Immunol 1990;144:2558-65.

22 Bøyum A. Isolation of lymphocytes from human bloodfurther observations (Paper II).Scand J Immunol 1976;5: $9-15$.

23 Cavender DE, Haskard DO, Joseph B, Ziff M. Interleukin-1 increases the binding of human $\mathrm{B}$ and $\mathrm{T}$ lymphocytes to endothelial cell monolayers. J Immunol 1986;136:203-7.

24 Lawrence MB, Springer TA. Leukocytes roll on a selectin at physiologic flow rates: distinction from and prerequisite for adhesion through integrins. Cell 191;65: 859-73.

25 Alon R, Kassner PD, Carr MW, Finger EB, Hemler ME, Springer TA. The integrin VLA-4 supports tethering and rolling in flow on CD106. J Cell Biol 1995;128:1243-53.

26 To SS, Newman PM, Hyland VJ, Robinson BG, Schrieber L. Regulation of adhesion molecule expression by human synovial microvascular endothelial cells in vitro. Arthritis Rheum 1996;39:467-77.

27 Chen XI-Lin L, Tummala PE, Olliff L, Medford RM. E-selectin gene expression in vascular Smooth muscle cells: evidence for a tissue-specific repressor protein. Circ Res 1997;80:305-11.

28 Marui N, Offermann MK, Swerlick R, Kunsch C, Rosen $\mathrm{CA}$, Ahmad M, et al. Vascular cell adhesion molecule-1 (CD106) gene transcription and expression are regulated through an antioxidant-sensitive mechanism in human vascular endothelial cells. J Clin Invest 1993;92:1866-74.

29 Montgomery KF, Osborn L, Hession C, Tizard C, Goff D, Vassallo C, et al. Activation of endothelial-leukocyte adhesion molecule-1 (ELAM-1) gene transcription. Proc Natl Acad Sci USA 1991;88:6523-7.

30 Neish AS, Read MA, Thanos D, Pine R, Maniatis T, Collins T. Endothelial interferon regulatory factor 1 cooperates with NF-kappa B as a transcriptional activtor of vascular with NF-kappa B as a transcriptional activtor of vascular
cell adhesion molecule 1. Mol Cell Biol 1995;15:2558-69.

31 Iademarco MF, Barks JL, Dean DC. Regulation of vascula cell adhesion molecule- 1 by IL- 4 and TNF $\alpha$ in cultured endothelial cells. J Clin Invest 1995;95:264-71.

32 Wellicome SM, Kapahi P, Mason JC, Lebranchu Y, Yarwood H, Haskard DO. Detection of a circulating form of vascular cell adhesion molecule-1: raised levels in rheumatoid arthritis and systemic lupus erythematosus. Clin matoid arthritis and systemic lup

33 Haskard D, Cavender D, Robin M, Fleck RM, Sontheimer $\mathrm{R}$, Ziff M. Human dermal microvascular endothelial cells behave like umbilical vein endothelial cells in T-cel adhesion studies. J Invest Dermatol 1987;88:340-3.

34 Tonnesen MG, Anderson DC, Springer TA, Knedler A Avdi N, Henson PM. Adherence of neutrophils to cultured human microvascular endothelial cells. Stimulation by chemotactic peptides and lipid mediators and dependence upon the Mac-1, LFA-1, p150,95 glycoprotein family. J Clin Invest 1989;83:637-46.

35 Perry MA, Granger DN. Role of CD11/CD18 in shear ratedependent leukocyte-endothelial cell interactions in cat mesenteric venules. J Clin Invest 1991;87:1798-804

36 Jones DA, McIntire LV, Smith WC, Picker LJ. A two-step adhesion cascade for $\mathrm{T}$ cell/ endothelial cell interactions under conditions of flow. J Clin Invest 1994;94:2443-50.

37 Elices MJ, Tsai V, Strahl D, Goel AS, Tollefson V, Arrhenius $\mathrm{T}$, et al. Expression and functional significance of alternatively spliced CS1 fibronectin in rheumatoid arthritis microvasculature. J Clin Invest 1994;93:405-16.

38 Berg EL, McEnvoy LM, Berlin C, Bargatze RF, Butcher EC. L-selectin mediated lymphocyte rolling on MAdCAM-1. Nature 1993;366:695-8.

39 Fuhlbrigge RC, Keiffer JD, Armerding D, Kupper TS Cutaneous lymphocyte antigen is a specialised form of PSGL-1 expressed on skin-homing T cells. Nature 1997;389:978-81.

40 Pitzalis C. Role of adhesion mechanisms in the pathogenesis of chronic synovitis. Br J Rheumatol 1996;35:1198-15.

41 Jones WM, Watts GM, Robinson MK, Vestweber D, Jutila MA. Comparison of E-selectin-binding glycoprotein liggamma delta T cells. J Immunol 1997;159:3574-83. 